\title{
Incidence of $\beta$-lactamases Among Novel Multidrug Resistant Clinical Isolates of UTI Patients: An Antimicrobial Resistance Surveillance Study
}

\author{
Rashmi M. Bhande - Kolhapure \\ School of Life Sciences, Swami Ramanand Teerth Marathwada University, Nanded, (MS) India \\ Email address: \\ bhanderashmi@gmail.com
}

\section{To cite this article:}

Rashmi M. Bhande - Kolhapure. Incidence of $\beta$-lactamases Among Novel Multidrug Resistant Clinical Isolates of UTI Patients: An Antimicrobial Resistance Surveillance Study. Science Research. Vol. 3, No. 6, 2015, pp. 329-343. doi: 10.11648/j.sr.20150306.20

\begin{abstract}
Community or Nosocomial Urinary Tract Infections (UTI) are increasing worldwide speedily by creating problem to currently available $\beta$-lactam antibiotic therapies. Thus it is an urgent need of research to find the effective therapeutic options to treat / manage the UTI. Therefore, the present work is designed to determine prevalence of $\beta$-lactam resistance in seven novel bacterial isolates from the community UTI as well as to identify and characterize the types of $\beta$-lactamases involved in UTI. Total Five Hundred and Forty Nine $(\mathrm{n}=549)$ clinical strains isolated from Urine samples and identified as $E$. coli, P. mirabilis, K. pneumoniae, P. aeruginosa, Enterobacter spp., Escherichia spp., Enterococcus spp., A. haemolyticus, Micrococcus, Serratia spp., Shigella spp., Staph. Aureus etc. Antimicrobial susceptibility profile of these strains revealed high level resistance to Ampicillin (99\%), Ceftazidime (98.99\%), Amoxicillin (98\%), Cefotaxime (99\%), Cefaclor (98\%) and Penicillin (99\%). Thus out of 549 only seven were detected as novel Extended Spectrum $\beta$-lactamase producers. All the seven isolates were identified at $16 \mathrm{~S}$ r RNA level and submitted to NCBI with following accession numbers such as: JX827388.1, JX827385, JX827384.1, JX827383.1, JX827382, JX827386 and JX827387. Minimum inhibitory concentration of each novel strain was determined against 25 different $\beta$-lactam antibiotics i.e. Ampicillin, Amoxiclav, Oxacillin, Vancomycin, Gentamycin, Ciprofloxacin, Nitrofurantoin, Ceftazidime, Cotrimaxazole, Trimethoprim, Imipenam, Amikacin, Amoxicillin, Cephalexin, Cefuroxime, Nalidixic acid, Cefazoline, Cefdinir, Cefexime, Ceftriaxone, Cefuroxime, Cefotaxime, Aztreonam, Cefaclor, Penicillin etc. All these strains revealed to possess virulence markers such as $\alpha$-hemolysin, Cell surface hydrophobicity, Aerobactin production, Serum Resisitance, Colicine production etc. In addition to this an antimicrobial surveillance of the same strain was tested for multiple antibiotic resistance scale with the help of WHONET software designed by World Health Organization.
\end{abstract}

Keywords: $\beta$-lactamases, Urinary Tract Infection, WHONET Software, Virulance Markers

\section{Introduction}

Urinary Tract Infection is the most common nosocomial bacterial infection encountered in human population from neonate to geriatric age groups [1]. The incidence of UTI is more in women as compared to men and prevalence increases substantially with increasing age (i.e. 5-10\% UTI for the age of 70 years and $\sim 10 \%$ UTI for the age of 80 years and older). In many parts of the world near about $80-85 \%$ Gram-negative enteric and 15-20\% Gram-positive microorganisms constitutes a serious problem in development of Urinary Tract Infection. Enteric bacteria (in particular E.coli) is the most frequent cause of UTI.
Multidrug resistant pathogens travel not only locally but also globally and hence spread rapidly in susceptible host [2]. For better decision- making of treatment, physicians need more information about local susceptibility pattern of Uropathogens. UTI can only be ascertained on the basis of microscopy and microbial culture of urine therefore it is rational to do bacteriological examination of urine sample along with their antibiogram.

$\beta$-lactamases which hydrolyze the amide bonds of the, $\beta$ lactam ring of sensitive Penicillins and Cephalosporins are widely distributed among microorganisms [3] and play important role in microbial resistance to $\beta$-lactam antibiotics. Extended spectrum $\beta$-lactamases (ESBLs) are capable of hydrolyzing Penicillins, Cephalosporins (including wide 
spectrum ones) and Monobactams, except for the Cefamicines and the Carbapenemics [4]. $\beta$-lactamase producing bacteria can cause serious therapeutic failure if not detected in time. Classical ESBLs evolved from Class A TEM (from TEM-1 or TEM-2) and SHV (from SHV-1) enzymes and these remain the most prevalent types of ESBLs though class D ESBLs (i.e. of the OXA family) have also been known for some time. Still over the past several years a plethora of non-TEM, non-SHV, non-OXA ESBLs have been reported in several organisms all over the world (eg. Families BES, GES, PER, TLA, VEB and CTX-M ) with CTX-M type ESBLs [5]. In contrast to the TEM-,SHV- and OXA- derived ESBLs which result for mutation of their narrow-spectrum counterparts many of the other ESBLs which are typically plasmid encoded or otherwise mobile originated from naturally occurring (i.e. chromosomal) enzymes are also considered. Variety of other $\beta$-lactamases which are plasmid mediated or integron -associated class A enzyme have been recently discovered. They are not simple point mutations of any known $\beta$-lactamases but they are characterized by their geographic diversity such as- VIM (Verona IntegronEncoded Metallo- $\beta$-Lactamase), KPC ( $K$. pneumoniae Carbapenemase) (Class A), NDM-1 (New Delhi metallo- $\beta$ lactamase), Amp-C, Inhibitor Resistant $\beta$-Lactamases, Chromosome-Mediated $\beta$-Lactamases, Extended Spectrum $\beta$ lactamases etc.

The emergence and dissemination of resistant bacteria is a natural process in which bacteria get adapted to a hostile environment rich in antibacterial agents. The multidrug resistance of the bacteria contributes to their survival and virulence. These virulence factors can act independently or their actions may be complementary to each other [6]. Virulence factors are very often responsible for causing diseases in the host as they inhibit certain host functions. Pathogen possesses a wide array of virulence factors. Some are intrinsic to the bacteria (eg. Capsule and endotoxin) whereas others are obtained from Plasmids (eg.some toxins). Besides bacterial adherence, several virulence factors may contribute to the pathogenicity, including the production of $\alpha$ hemolysin, Colicin, Aerobactin and Serum resistance [7]. Enterobacteriaceae uropathogens present in the gastro intestinal tract initiates the UTI. These isolates express chromosomally encoded virulence markers. These markers of Uropathogenic E.coli (UPEC) are expressed with different frequencies in different disease states ranging from asymptomatic bacteriuria to chronic pyelonephritis. It is now recognized that there are a subset of fecal E.coli having the above mentioned factors which can colonize periurethral area, enter urinary tract and cause symptomatic disease.

The treatment with an antimicrobial is decided either on the basis of antibiogram of the individual isolate or if sensitivity testing data is available on the basis of $\%$ Resistant $(\% \mathrm{R})$ and / or $\%$ Sensitive $(\% \mathrm{~S})$ bacterial population. Sensitivity Index of antimicrobial, (SI) calculated from percent Resistant Intermediate Sensitive (\%RIS) results generated using standard NCCLS., 2000, testing method [8] and uniform analysis by WHONET 5.6, might be a uniform and better criterion for rational use of antimicrobials. To satisfy the urgent need for an efficient surveillance system to monitor the possible impact of this policy, and to study the epidemiology of antimicrobial resistance, we used WHONET 5.6 software (project 2009-2011) to establish a regional network for continuous monitoring of such resistance. This study is based on the assumption that the routine results of the antimicrobial sensitivity tests performed daily in clinical laboratory should be considered to be a major resource for resistance surveillance. To do this we studied our isolates with the help of WHONET software. The World Health Organization has established a program to tackle the problem of antimicrobial resistance which is known as Antimicrobial Resistance Monitoring (ARM) program. It requires accurate and easily accessible data on antimicrobial resistance to support decision making and to take action from local to the global level.

Hence, The present study was therefore undertaken to find out the presence of different $\beta$-lactamases from hospitalized patients in Nanded District using standard methods presently available for their detection as well as an attempt was made to correlate the pathogenecity of all isolated pathogens from UTI patient with different virulent factors i.e. Haemolys in production, Cell surface hydrophobicity, Serum resistance, Colicin and Aerobact in production. Realizing the high prevalence of drug resistance in bacterial population, the study was aimed to find out the surveillance of drug resistance. This data was analyzed with the help of WHONET 5.6 software. The data presented cover the period June 2009-December 2011.

\section{Materials and Methods}

\subsection{Study Population / Cases}

The study population was drawn from patients attending Government Medical College and Hospital, Nanded for a period of six month from July 2009 - January 2010.Urine samples from 360 cases (both male and female of age 5-70 years) of UTI and 30 normal controls from department of Urology, Nephrology, Medicine, Pediatrics and few other departments of hospital were studied. Patients on antibiotic therapy were excluded from study.

\subsection{Collection of Urine Sample}

Early morning mid-stream urine samples were collected using Sterile (dry heat at $160^{\circ} \mathrm{C}$ for $1 \mathrm{~h}$ ) wide mouthed sterile plastic container (HiMedia) with screw cap tops with name, age, sex, time of collection of the patients prior to antimicrobial treatment and transported immediately to laboratory in an ice-cold condition by adding boric acid (1.8\%) $[9,10]$. The samples were analyzed bacteriologically [11].

\subsection{Sample Processing}

\subsubsection{Culture}

a) A calibrated sterile platinum wire loop $(0.4 \mathrm{~mm}$ diameter) for the semi-quantitative method was used for 
the plating. A loopful $(0.01 \mathrm{ml})$ of well mixed each urine sample was inoculated into duplicate plates of Blood and Mac Conkeys agar. All plates were then incubated at $37^{\circ} \mathrm{C}$ aerobically for $24 \mathrm{~h}$. The plates were examined microscopically for bacterial growth and colonies were counted and multiplied by 100 to give an estimate of the number of bacteria present per milliliter of Urine. A significant bacterial count was taken as any count equal to or in excess of 10,000 CFU/ml [12].

b) A fresh voided urine sample provided by the patient were used for Dipstick and /or Leukocyte esterase test. Subsequently, a Dipslide (Uriline, 56508; BioMeurex, Plainview, NY) was prepared according the manufacturer's instructions. On the day of sample collection the Dipslide was incubated at $37^{\circ} \mathrm{C}$ for $16-20$ h. Thereafter, growth on the Dipslides was compared with a chart provided by the manufacture and recorded from no growth to $\geq 10^{7}$ colony-forming units (CFU/ml).Bacterial growth on the dipslides of $\geq 10^{3}$ $\mathrm{CFU} / \mathrm{ml}$ was identified using standard biochemical tests [13].

\subsubsection{Microscopy}

All Urine samples were centrifuged at $5000 \mathrm{rpm}$ for $5 \mathrm{~min}$ separately. A $0.1 \mathrm{ml}$ volume of Urine was applied to a glass microscope slide, allowed to air dry, stained with gram stain and examined microscopically. The deposits were examined using both $\times 10$ and $\times 40$ objectives. Samples with $\geq 10$ white blood cells $/ \mathrm{mm}^{3}$ were regarded as pyuric [14]. Bacterial isolates were identified generally using a battery of tests [15]. All urine samples having growth of single morphotype of colony counts of $10^{4}-10^{5}$ colonies $/ \mathrm{ml}$ was considered probably significant and a count of $<10^{4}$ colonies $/ \mathrm{ml}$ as significant growth of Perennial or Uretral flora [16].

\subsection{Isolation and Identification of UTI Isolates}

For isolation of almost all uropathogens a loopful of urine sample $(n=360)$ was streaked on 7 different selected and differential growth media viz. Mac Conkey's agar, Blood agar, CLED (Cysteine Lactose Electrolyte Deficient) agar, Nutrient agar, EMB (Eosin Methylene Blue) Agar, UTI agar and combinational agar (CLED + Mac Conkey's + Blood) and incubated at $37^{\circ} \mathrm{C}$ for $24 \mathrm{~h} \mathrm{[17].} \mathrm{After} \mathrm{incubation}$ colonies were selected and characterized on the basis of morphological, cultural, Typical and Atypical biochemical tests and differentiated according to bacterial molecular identification procedure of $16 \mathrm{~S}$ rRNA.

\subsection{Screening of Uropathogens for MAR Antibiogram with Respect to $\beta$-lactam Class}

All identified uropathogens were subjected to antimicrobial sensitivity test (AST) on Muller-Hinton agar by Kirby-Bauer Disc Diffusion method [18]. About 0.5 Mac Farland cell density adjusted microbial suspension was swab inoculated on pre-sterilized Muller-Hinton agar plates. 25 different antibiotics specified for uropathogens, $\beta$-lactam class (HiMedia) were used for the test. Plates were incubated at $37^{\circ} \mathrm{C}$ for $24 \mathrm{~h}$. The sensitivity of isolate towards each antimicrobial agent was evaluated by comparing the zone of inhibition with standard interpretative chart as recommended by NCCLS and results were categorized in to Resistant, Sensitive and Intermediate (NCCLS, 2000). The E. coli (ATCC 25922) was used as a positive control. Antimicrobial discs with potency used for Gram negative bacteria were Ampicillin $(30 \mu \mathrm{g})$; Amoxiclav $(30 / 10 \mu \mathrm{g})$; Oxacillin $(30 \mu \mathrm{g})$; Vancomycin $(30 \mu \mathrm{g})$; Gentamycin $(10 \mu \mathrm{g})$; Ciprofloxacin $(30 \mu \mathrm{g}) ; \quad$ Nitrofurantoin $\quad(10 \mu \mathrm{g}) ; \quad$ Ceftazidime $(30 \mu \mathrm{g})$; Cotrimaxazole $(30 \mu \mathrm{g})$; Trimethoprim $(30 \mu \mathrm{g})$; Imipenam $(10 \mu \mathrm{g}) ; \quad$ Amikacin $(10 \mu \mathrm{g}) ; \quad$ Amoxicillin $(30 \mu \mathrm{g})$;

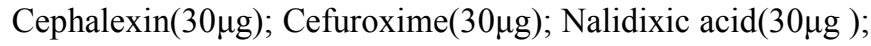
Cefazoline $(30 \mu \mathrm{g})$ Cefdinir(30 $\mu \mathrm{g})$; Cefexime $(30 \mu \mathrm{g})$; Ceftriaxone $(30 \mu \mathrm{g})$; Cefuroxime $(30 \mu \mathrm{g})$; Cefotaxime $(30$ $\mu \mathrm{g})$; Aztreonam $(30 \mu \mathrm{g})$; Cefaclor $(30 \mu \mathrm{g})$ and Penicillin

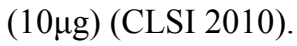

The Multiple Antibiotic Resistance Indices (MARi) were calculated as follows:

MAR index for isolates

$=\frac{\text { Number of antibiotics to which the isolate is resistance }}{\text { Number of antibiotics tested }}$

\subsection{Extended Spectrum B-lactamase Test}

Presence of Extended spectrum $\beta$-lactamases were determined by modified Double Disc Synergy Test (DDST) [19]. The 0.5 Mac Farland turbidity adjusted bacterial test strains were swab inoculated on Muller-Hinton agar plates (HiMedia) and 3G Cephalosporin i.e. Cefotaxime $(30 \mu \mathrm{g})$, Ceftazidime $(30 \mu \mathrm{g})$ were placed $15 \mathrm{~mm}$ apart from a disc of Amoxicillin plus Clavulanic acid (augmentin $20 \mu \mathrm{g}+10 \mu \mathrm{g}$ ) at the center of a Petri-dish and incubated at $37^{\circ} \mathrm{C}$ for $18-24$ h. An enhanced zone of inhibition between any one of the $\beta$ lactam disc towards the augmentin disc was interpreted as presumptive evidence for the presence of ESBLs [20].

\subsection{Metallo $\beta$-lactamase Test}

Presence of Metallo $\beta$-lactamase was determined by modified Combined Imipenem-EDTA (IMP-EDTA Combined Disc Test) [21]. Screened ESBL positive isolates were swab inoculated on Muller-Hinton agar (HiMedia) plates as per the CLSI guidelines. Two Imipenem disc $10 \mu \mathrm{g}$ (HiMedia) were placed on plate and appropriate amount of $10 \mu \mathrm{l}$ of EDTA solution was added to one of them so as to make the final concentration $750 \mu \mathrm{g}$. Inhibition zones were compared after $16-18 \mathrm{~h}$ of incubation at $37^{\circ} \mathrm{C}$. Isolates were considered as MBL positive when inhibition zone increases with the imipenem and EDTA disc $\geq 7 \mathrm{~mm}$ than the Imipenem disc alone.

\subsection{Amp C B-lactamases Test}

Presence of Amp C $\beta$-lactamases was detected by Modified Three Dimensional Extract Method (TDEM) [22]. A 0.5 Mac Ferland $(50 \mu \mathrm{l})$ resistant bacterial suspension was inoculated into $12 \mathrm{ml}$ of Trypticase Soy Broth and was 
incubated at $37^{\circ} \mathrm{C}$ for $24 \mathrm{hrs}$. The MHA plate surface was inoculated with E.coli ATCC25922 (Sensitive to Cefoxitin) as described standard Disk diffusion method. A $30 \mu \mathrm{g}$ Cefoxitin disk was placed at the center of the inoculated plate. With a sterile scalpel blade, a liner slit beginning $5 \mathrm{~mm}$ from the edge of the disk was cut in agar in an outward radial direction. Overnight incubated fresh bacterial suspension was picked with sterile wire loop and the slit was inoculated at depth, beginning near the disc and moving outwards with a heavy inoculums. The plates were incubated at $37^{\circ} \mathrm{C}$ for overnight. Enhanced growth of the surface organism (E.coli) at the point where slit intersected the zone of inhibition was considered a positive result and was interpreted as evidence for the presence of Amp C $\beta$-lactamase.

\subsection{B-lactamase Iodometric Test}

Existence of $\beta$-lactamase enzyme in each isolate was quantitavely determined by modified iodometric method [23]. Briefly, the starch indicator solution containing $1.0 \mathrm{~g}$ of soluble stach (Merk) in $100 \mathrm{ml}$ of Distilled water was prepared fresh each day or two. The iodine reagent contained a mixture of $2.03 \mathrm{~g}$ of iodine and $53.2 \mathrm{~g}$ of potassium iodide which dissolved in $100 \mathrm{ml}$ of distilled water and stored in a brown glass bottle. The $0.05 \mathrm{M}$ of Phosphate buffer of $\mathrm{pH}$ $5.8,7,8$ was made. A solution containing 10,000U of Penicillin $\mathrm{G}$ per $\mathrm{ml}$ of phosphate buffer was freshly prepared and dispensed in $0.5 \mathrm{ml}$ volumes in small vials. A $0.5 \mathrm{Mac}$ Ferland freshly prepared test bacterial solution was added in to vial and incubated for $1 \mathrm{hr}$. After $1 \mathrm{hr}$ or longer at room temperature, two small drops of starch indicator were added to the suspension, followed after mixing by one small drop of iodine reagent. A blue color was immediately developed due to the reaction of iodine with starch. The reaction mixture was further rotated for up to $1 \mathrm{~min}$. Persistence of blue color for longer than $10 \mathrm{~min}$ constituted a negative test and indicated that the Penicillin molecules had not undergone $\beta$ lactam ring cleavage. Rapid decolorization is considered as positive test. Two tubes of Penicillin solution without bacteria served as controls, one tube received drops of starch and iodine at the beginning of the hour, and the second control tube was held until the end of the hour when the reagents were added to the tests. Retention of the blue color by both controls for the duration of the test period testified to be the absence of spontaneous Penicillin hydrolysis or possible hydrolysis by enzymes of microorganisms that might contaminate the starch or buffer solutions.

\subsection{B-lactamase Nitrocefin Test}

$\beta$-lactamase Nitrocefin Test [24] is the gold standard method for rapid determination of $\beta$-lactamase activity. A working solution of Nitrocefin was prepared by adding 0.5 $\mathrm{ml}$ of Dimethyl Sulfoxide to $5 \mathrm{mg}$ of Nitrocefin powder (Calbiochem, UK). A $0.5 \mathrm{ml}$ of $0.1 \mathrm{M}$ Phosphate buffer ( $\mathrm{pH}$ 7.0 ) is added to make a final Nitrocefin concentration of 500 $\mu \mathrm{g} / \mathrm{ml}$ (frozen at $-20^{\circ} \mathrm{C}$ ). A loopful of test organism was removed from colonial growth and emulsified in one drop of the above prepared Nitrocefin solution $(500 \mu \mathrm{g} / \mathrm{ml})$ on a clean glass test tube. A change in color from yellow to red within $15 \mathrm{~min}$ indicates a positive reaction.

\subsection{Determination of Minimum Inhibitory (MIC) and Minimum Bactericidal Concentration (MBC)}

MIC of all confirmed $\beta$-lactamase producers were determined by Tube Dilution method [25]. About 25 different antibiotics i.e. Ampicillin, Amoxiclav, Oxacillin, Vancomycin, Gentamycin, Ciprofloxacin, Nitrofurantoin, Ceftazidime, Cotrimaxazole, Trimethoprim, Imipenam, Amikacin, Amoxicillin, Cephalexin, Cefuroxime, Nalidixic acid; Cefazoline, Cefdinir, Cefexime, Ceftriaxone, Cefuroxime, Cefotaxime, Aztreonam, Cefaclor, Penicillin specified for uropathogens, $\beta$-lactam class (HiMedia) in the range from $240-0.01 \mathrm{mg} / \mathrm{ml}$ were prepared in $3 \mathrm{ml}$ nutrient broth, 0.5 Mac Farland turbidity adjusted confirmed $\beta$ lactamase positive culture was added into each test tube individually. Similar test tube set containing all above cited antibiotics were treated as control group. Test tubes were incubated at $37^{\circ} \mathrm{C}$ for $24 \mathrm{~h}$ and examined for turbidity. After incubation, tube containing least concentration of drugs showing no visible sign of growth was considered as the minimum inhibitory concentration (MIC). Tubes showing positive MIC were further continued for determination of $\mathrm{MBC}$ on sterile Muller-Hinton Agar plates.

\subsection{Virulence Characterizations}

\subsubsection{Hemolysin Production}

Production of hemolysin was assayed on Sheep blood agar plates [26]. All isolates were grown overnight at $37^{\circ} \mathrm{C}$ in LB medium. $50 \mu 1$ of 0.5 Mac Ferland turbidity adjusted culture was streaked on sheep blood agar plate and incubated overnight at $37^{\circ} \mathrm{C}$. Hemolysin production was verified by the presence of a clear hemolytic halo around the colonies.

\subsubsection{Colicin Production}

Colicin production was evaluated by the Agar overlay method [27]. All isolates were cultured in tryptic soy broth at $37^{\circ} \mathrm{C}$ overnight and plated onto tryptic soy agar. The colonies obtained after overnight incubation at $37^{\circ} \mathrm{C}$ were killed with chloroform and overlaid with $3 \mathrm{ml}$ soft Tryptic Soy agar containing Colicin indicator strain (E.coli $\mathrm{K}_{12}$ ATCC 23559). After overnight incubation at $37^{\circ} \mathrm{C}$, the capacity of colicin production was detected by the presence of a halo around the producer colonies.

\subsubsection{Cell Surface Hydrophobicity}

Cell surface hydrophobicity was tested by Salt aggregation test [28]. Bacteria were tested for their hydrophobic property by using different molar concentrations of ammonium sulfate. Those bacteria which aggregated with salt particles and formed the clumps were considered to be hydrophobic. A strain of E.coli which was haemolytic, MRHA positive and consistently positive for cell surface hydrophobicity was used as positive control whereas a strain which was nonhemolytic, negative for MRHA and consistently negative for 
cell surface hydrophobicity was used as negative control. All isolates grown on MHA plates were inoculated into $1 \mathrm{ml}$ of PBS pH 6.8 and 0.5 Mc Farland turbidity matched tubes to get a colony count of $5 \times 109$ colonies $/ \mathrm{mL}$. Different molar concentrations of ammonium sulfate namely $1 \mathrm{M}, 1.4 \mathrm{M}$ and $2 \mathrm{M}$ were prepared. About $100 \mu \mathrm{l}$ of $0.2 \mathrm{M}$ PBS (pH 6.8)was taken in clean sterilized petri plate and $100 \mu \mathrm{l}$ of $1 \mathrm{M}, 1.4 \mathrm{M}$ and $2 \mathrm{M}$ concentrations of ammonium sulphate were taken in another petri plates. Then $100 \mu \mathrm{l}$ of each isolate suspension was added to each of these plates. The clumps formed in different molar concentrations of ammonium sulphate was observed under Leights Wetzlar inverted microscopebinocular $(0.32)$ at $20 \times$ magnification and scored positive on one to four scale $(1+$ to $4+)$.Strains were considered hydrophobic if they aggregated in concentrations of $1.4 \mathrm{M}$. Isolates which gave doubtful results were retested.

\subsubsection{Aerobactin Production}

Production of aerobactin was assayed by growing the strains isolated in a LB medium containing $200 \mu \mathrm{M}$ of $\alpha, \alpha$ dipyridyl for $24 \mathrm{~h}$ at $37^{\circ} \mathrm{C}$, without shaking. The grown mass was spun for $3 \mathrm{~min}$ at $12000 \mathrm{~g}$, the supernatants filtered through a $0.22 \mu \mathrm{m}$ nitrocellulose membrane and $50 \mu \mathrm{l}$ aliquots added to orifices made in a LA medium [26], previously seeded with strain LG 1522 [29].Petri dishes were kept at $37^{\circ} \mathrm{C}$ for $48 \mathrm{~h}$ and the production of aerobactin visualized by the growth of strain LG 1522 around the orifices.

\subsubsection{Serum Inactivation Assay}

Serum inactivation assay was performed by the standard method [30]. All the isolates were inoculated at $0.1 \%(\mathrm{v} / \mathrm{v})$ inoculums level into glucose phosphate broth containing bromothymol blue and $2 \%$ human serum and incubated at $37^{\circ} \mathrm{C}$ for $24 \mathrm{~h}$. The serum resistance was observed by change in color from green to yellow and extinction of yellow color was measured at $500 \mathrm{~nm}$.

\subsection{WHONET Antimicrobial Surveillance Study}

\subsubsection{Participating Hospitals}

The present study was conducted in the School of Life Sciences (Biotech Lab), SLS, S.R.T.M.U. Nanded (MS), India from June 2009 to June 2010 of five different pathology laboratories from Nanded city. To participate in the network the main prerequisite is the availability of a PC installed with WHONET software. All data were entered into the program, if possible on a daily basis. Data entry was done either manually (for hospitals using the disc diffusion method for sensitivity testing) or by automatic download with the aid of BACLINK software (available upon request from Dr J. Stelling, Communicable Disease Surveillance and Response Programme, World Health Organization, Geneva). Each laboratory was asked to agree to make available all electronic files for purposes of preparing multicentre reports.

\subsubsection{Isolation and Identification of Pathogenic Bacteria}

Isolation of pathogenic bacteria from clinical specimens and identification to the species level was performed by standard methods as mentioned above.

\subsubsection{Sensitivity Testing}

The sensitivity testing methods used were as follows: Kirby \pm Bauer disc diffusion. The zone diameters or minimum inhibitory concentrations (MICs). Antibiotics were selected according to WHO model list of essential drugs. $\beta$-lactamase production was assessed by Nitrocefin test method. NCCLS breakpoints for third generation Cephalosporins have recently been revised to detect ESBL production.

\subsubsection{Quality Control}

Escherichia coli (ATCC 25922), Staphylococcus aureus (ATCC 25923) and Pseudomonas aeruginosa (ATCC 27853) strains were used as internal quality controls. Moreover, the External Quality assurance scheme was organized by the WHO Collaborating Centre for monitoring International Bacterial Resistance to Antimicrobial Agents, Centers for Disease Control and Prevention, Atlanta, GA, USA.

\subsubsection{Data Reporting}

Main prerequisite for compilation of data was a PC installed with WHONET software. All data was entered into the program manually on a daily basis. A large number of permutation combinations were available in the program for analysis.

\section{Results and Discussion}

Identification of uropathogen and their susceptibility pattern is an important criteria to treat Urinary Tract Infections (UTIs). In the present study, Urine specimens were cultured to see pattern of uropathogens. Prior antibiotic therapy clinical conditions like non-gonococcal urethritis or others UTI could be the factors responsible for insignificant bacteriurea. No growth indicates the need for educating the patients about the method of collection of clean catch midstream urine specimens.

Table 1. Urine culture test.

\begin{tabular}{lll}
\hline \multirow{2}{*}{ Diagnostic Tests } & \multicolumn{2}{c}{ Urine culture } \\
\cline { 2 - 3 } & $\mathbf{2} \mathbf{1 0}^{\mathbf{3}} \mathbf{C F U} / \mathbf{m L}$ & $\mathbf{1 0}^{\mathbf{3}} \mathbf{C F U} / \mathbf{m L}$ \\
\hline Nitrite test in all patient & 204 & 7 \\
Positive & 156 & 126 \\
Negative & 132 & 93 \\
Leukocyte esterase test in cases of nitrite negative tests \\
Positive & 24 & 33 \\
Negative &
\end{tabular}

$\mathrm{n}=360$

Out of 360 collected urine samples 336 (82.44\%) urine samples revealed significant culture positive urine test (Table 1). In case of the performance charactericteristic of the diagnostic tests out of 360 UTI positive samples 204 specimen showed positive nitrite with $\geq 10^{3} \mathrm{CFU} / \mathrm{mL}$, whereas 132 positive specimens showed Leucocyte esterase positive in cases of nitrite negative tests (Table 1). These tests can reveals prevalence of UTI in relation to age and sex of patients. Age and Size distribution of the culture-positive cases, $36(10.71 \%)$ were children aged 10 years or less, and $46(12.79 \%)$ were aged 60 years and above. The age group 
41-60 exhibited highest growth of uropathogens i.e.113 $(33.63 \%)$. In all age groups, except those aged $0-10$ years, females were frequently affected than males (Table 2). The age and Sex distribution of the patients followed the natural epidemiologic pattern of UTI. There was a predominance of young and middle aged females, whereas in the older age groups of more than 60 years 1:2 proportions of male and female had UTI.

Table 2. Age and Size distribution of the culture positive Urine samples.

\begin{tabular}{llll}
\hline $\begin{array}{l}\text { Age groups } \\
\text { (years) }\end{array}$ & No of samples & \multirow{2}{*}{ Total } \\
\cline { 2 - 3 } & Male & Female & \\
\hline $0-10$ & 15 & 21 & $36(10.71 \%)$ \\
$11-20$ & 22 & 34 & $56(16.66 \%)$ \\
$21-40$ & 23 & 62 & $85(25.29 \%)$ \\
$41-60$ & 26 & 87 & $113(33.63 \%)$ \\
Above 60 & 15 & 31 & $46(12.79 \%)$ \\
Total & 101 & 235 & $336(82.44 \%)$ \\
\hline
\end{tabular}

$\mathrm{n}=360$

Table 3. The Microscopic examination of Urine samples.

\begin{tabular}{lll}
\hline Bacteriuria and Pyuria & No & Percentage (\%) \\
\hline Significant Pyuria & 130 & $38.69 \%$ \\
In Significant Pyuria & 170 & $50.59 \%$ \\
Significant pyuria with Growth & 125 & $37.20 \%$ \\
Significant pyuria without growth & 12 & $3.57 \%$ \\
Significant pyuria with insignificant growth & 17 & $5.05 \%$ \\
\hline
\end{tabular}

$\mathrm{n}=336$

Microscopic examination of the centrifuged urine revealed that out of 336 culture positive urine samples 130 (46.93\%) specimen showed significant pyuria (pus cells of 5 cell/hpf) while $170(61.37 \%)$ showed insignificant pyuria (pus cells of 1-2 cells / hpf). Out of 130 significant pyuritic samples, 125 (37.20\%) yielded significant bacterial growth, 17(5.05\%) insignificant bacterial growth while $12(3.57 \%)$ yielded no bacterial growth (Table 3 ). The presence of simple bacteriuria particularly in females should not be neglected; it may act as a risk factor for urinary tract infection. The prevalence of bacteriuria in female population increases gradually with time reaching 5\% in women of child bearing age and 10-20\% in post menopausal age. In our study 130 out of 336 female patients $(38.69 \%)$ showed significant bacteriuria. The presence of pus cells in urine (pyuria) is an indication of the Urinary Tract Infection. In one of the reported study it has been observed that approximately $75 \%$ of the patients with urinary tract infection have pyuria which is in close conformity with our study [31].

In case of uropathogen isolation, of the 549 isolates obtained, Gram-negative bacteria had a higher frequency of occurrence than Gram-positive isolates. These includes: E. coli 262 (47.72\%); Pseudomonas aeruginosa 45 (8.19\%); Proteus mirabilis $47(8.56 \%)$ Klebsiella pneumoniae 44 (8.01\%), Enterobacter spp. 33(6.01\%), Eschirichia spp. 12(2.18\%), Acinetobacter haemolyticus 18(3.27\%) Serratia spp.11 (2\%), Micrococcus spp. 5(0.91\%), Shigella spp 18(3.27\%) and Enterococcus spp. 25(4.60\%). Gram positive bacteria accounted for $40(22.22 \%)$ of the isolates like
Staphylococcus aureus 28 (5.10\%). It was also found that the rate of isolates of $E$. coli and $P$. aeruginosa were higher in isolates exclusively from females (Table 4). The most common organism isolated in these patients were $E$. coli (47.72\%), P. aeruginosa (8.19\%), P. mirabilis (8.56\%) and $S$. aureus $(5.10 \%)$. This finding is similar to other reports [15] which indicate that a Gram-negative bacterium, particularly E. coli, is the commonest pathogen isolated in patients with UTI. In this study, the prevalence of UTI in females is more than in males. Of the 549 isolates obtained, 394 were from female patients while 154 were from male. This is in agreement with reports (Cheesbrough, 2000) which states that UTI is more frequent in females than in males, during youth and adulthood. We isolated total 549 uropathogens from 130 significant culture positive urine samples and differentiated according to bacterial identification procedure of Bergey's Manual of Determinative Bacteriology as well as molecular identification system. Results revealed wide number of different uropathogens which indicate the urine samples were severely infected by number of bacteria hence the patient need quick and proper treatment.

Table 4. Isolation of uropathogens among 130 significant positive Urine culture Test.

\begin{tabular}{|c|c|c|c|c|c|c|}
\hline \multirow{3}{*}{ Isolates } & \multicolumn{4}{|l|}{ Sex } & \multirow{2}{*}{\multicolumn{2}{|c|}{$\begin{array}{l}\text { Among all } \\
\text { subjects }\end{array}$}} \\
\hline & \multicolumn{2}{|c|}{ Female } & \multicolumn{2}{|c|}{ Male } & & \\
\hline & No & $\%$ & No & $\%$ & No & $\%$ \\
\hline E.coli & 222 & 56.34 & 40 & 25.97 & 262 & 47.72 \\
\hline Proteus mirabilis & 31 & 7.9 & 16 & 10.38 & 47 & 8.56 \\
\hline $\begin{array}{l}\text { Klebsiella } \\
\text { pneumoniae }\end{array}$ & 33 & 8.37 & 11 & 7.14 & 44 & 8.01 \\
\hline $\begin{array}{l}\text { Pseudomonas } \\
\text { aeruginosa }\end{array}$ & 24 & 6.09 & 21 & 13.05 & 45 & 8.19 \\
\hline Enterobacter spp & 21 & 5.32 & 12 & 7.79 & 33 & 6.01 \\
\hline Escherichia spp. & 5 & 1.26 & 7 & 4.54 & 12 & 2.18 \\
\hline $\begin{array}{l}\text { Staphylococcus } \\
\text { aureus }\end{array}$ & 9 & 2.28 & 19 & 12.33 & 28 & 5.10 \\
\hline $\begin{array}{l}\text { Acinetobacter } \\
\text { haemolyticus }\end{array}$ & 11 & 2.83 & 7 & 4.54 & 18 & 3.27 \\
\hline Serratia spp & 5 & 1.26 & 6 & 3.89 & 11 & 2.00 \\
\hline Micrococcus & 2 & 0.50 & 3 & 1.94 & 5 & 0.91 \\
\hline Shigella spp. & 17 & 4.31 & 1 & 0.64 & 18 & 3.27 \\
\hline Enterococcus spp & 13 & 3.29 & 12 & 7.79 & 25 & 4.60 \\
\hline Total & 394 & 100.00 & 154 & 100.00 & 549 & 100.00 \\
\hline
\end{tabular}

No. reflects the number of isolates. P-value $=0.03$

The in-vitro antibiotic sensitivity pattern of the isolates to common anti-microbial agents is shown in Fig 1. Results indicated that Ampicillin, Ceftazidime, Amoxicillin, Ceftriaxone, Cefazoline, Cefdinir are the most ineffective antibiotics against isolated MDR pathogens. E.coli was the principle pathogen isolated showing a high susceptibility to Nitrofurantoin (85\%), Imipenem (80\%), Amikacin $(80 \%)$, Amoxicillin (75\%) but showed variable sensitivity to other commonly used antibiotics. E.coli having MARi Index 0.9 revealed highest drug resistance to Amipicillin (99\%), Ceftazidime (98.99\%), Amoxicillin (98\%), Ceftriaxone (99\%), Cefuroxime (98\%), Cefotaxime (99\%), Cefaclor (98\%), and Penicillin (99\%). In the present study, Klebsiella species (MARi index 0.8) showed high susceptibility to 
Imipenem (100\%) and Amkacin (85\%) but were relatively resistant to commonly used $\beta$-lactam antibiotics. Proteus species were $100 \%$ susceptible to Imipenem, $50 \%$ to Amikacin, Nitrofurantoin, Ceftriaxone and Amoxiclav each as per the earlier findings [32]. Pseudomonas species (MARi index 0.84), a common cause of hospital-acquired UTI was found resistant to Imipenem (100\%), Amikacin (75\%), Ceftazidime (95\%). Pseudomonas species were relatively susceptible to the second line of anti-Pseudomonas drugs and most of these were associated with high-level resistance to the first line antibiotics investigated namely Amoxiclav, Ceftriaxone, Ciprofloxacin and Gentamicin. This may be due to widespread use of common antibiotics in the hospitals and cross-resistance among different bacteria. Similar results were reported by other investigators [33, 34].

Table 5. Molecular Identification of $\beta$-lactamase producing uropathogens.

NCBI Submission (2012): Escherichia fergusonii strain GCR -1, Shigella flexneri strain DMB- 1, Enterococcus faecalis strain ADR-1, Shigella flexneri strain SMB-11,Enterobacter cancerogenus strain MAB-1,Shigella dysenteriae strain CNK-77,Enterobacter cowanii strain RMB-3.

- Escherichia fergusonii strain GCR -1; GenBank: JX827388.1

Agcatatctaccgtgggaggeggctccgaaggttaacctacctacttctttgctacccactcccatggggtgacgggeggtgtgtacaaggecegggaacgtattcacegtggcattctgatccacgattactagcgattccgacttcatg gagtcgagttgcagactccaatccggactacgacgcactttatgaggtccgcttgctctcgcgaggtcgcttctcttgtatgctccattgtagcacgtgtgtagccctggtcataaggggcatgatgacttgacgtcatccccaccttcctcc ggtttatcactggcagtctcctttgagttcccggccggaccgctggcaacaaaagataagggttgcgctcgttgcgggacttaacccaacatttcacaacacaagctgacaacagccatgcagcacctgtctcacggttcccgaaggcaa attctcatctctgaaaacttccgtggatgtcaagaacaggtaagggtcttccegttgcatccaattaaaccacatgctccaccgettgtgegggecccegtcaattcatttgaattttaaccttgeggacgtactccecaggcggtagacttaac gcgttagctccggaagccacgcctcagagacacaacatcccagtcgacatcgettacggcgtgtactacccggggatctaataccgtgtgttccccacacttctcacctgaccgtcagtcttcgtcaacggagacgecttctccccccgg atgcctccccatctctacgcatttcaccgctacacctgggattctaccetcctctectatactcaagcttgccactatcacaagcgactccccacgtgagcccggggatttctcatctgacactaaaaagagcgegcgtgcgctttacgcccc gtaattttcgattacacttgcgecctccacattatagcgectgctggtgacgaatttgccgggettcttctgctagtaacgtcatgagcacagcagtactcactcegtgcctccegctgcaagtaagttacagatcaagacctctctacaccccg catgctgcctcacgttggcccattgccaaatatccatgcgectccgtaggacggagcgggttcgagtcagtgtggaatccttcaacgctagactcgecatggaagcgtaccagccatcatgcctggaactcatgacagcctaggccetct atgctcgccegcttatgacgaatgact

- Shigella flexneri strain DMB-1 ; GenBank: JX827385

gctacacatg cagtcgaacc gagtgagcag cgcaagcaag cttgctgctt tgctgacgag tggeggacgg gtgagtaatg tctgggaaac tgcctgatgg agggggataa ctactggaaa cggtagctaa taccgcataa cgtcgcaaga ccaaagaggg ggaccttcgg gcctcttgccatcggatgtg cccagatggg attagctagt aggtggggta acggctcacc taggegacgatccctagctg gtctgagagg atgaccagcc acactggaac tgagacacgg tccagactc ctacgggaggc agcagtgggg aatattgcac aatgggcgca agcetgatgc agccatgccg cgtgtatgaa gaaggcettc gggttgtaaa gtacttcag cggggaggaa gggagtaaag ttaatacctt tgctcattga cgttacccgc agaagaagca ccggctaact ccgtgccagc agccgcggta atacggaggg tgcaagcgtt aatcggaatt actgggcgta aagcgcacgc aggeggtttg ttaagtcaga tgtgaaatcc ccgggctcaa cctgggaact gcatctgata ctggcaagct tgagtc

- Enterococcus faecalis strain ADR-1 ; GenBank: JX827384.1

tacacatgca gtcgaacgct gtgctatcca tcccgagtgc ttgcactcaa ttgaaaagaggacgggegga cgggggagta acacgtgggt aacctaccca tcagaggggg ataacacttg gaaacaggtg ctaataccgc ataacagttt atgecgcatg gcataagagt gaaaggegct ttcgggtgtc getgatggat ggaccegcgg tgcattagct agttggtgag gtaacggctc accaaggeca cgatgcatag ccgacctgag agggtgatcg gccacactgg gactgaga cacggcccagac tcctacggga ggcagcagta gggaatcttc ggcaatggac gaaagtctga ccgagcaacg ccgcgtgagt gaagaaggtt ttcggatcgt aaaactctgt tgttagagaa gaacaaggac gttagtaact gaacgtcccc tgacggtatc taaccagaaa gccacggcta actacgtgcc agcagccgeg gtaatacgta ggtggcaagc gttgtccgga tttattgggcgtaaagcgag cgcaggcgg

- Shigella flexneri strain SMB-11 ; GenBank: JX827383.1

ctacacatgc agtcgaacgg tagcagcgca aacagcttgc tgtttcgctg acgagtggcggacgggtgag taatgtctgg gaaactgcct gatggagggg gataactact ggaaacggtagctaataccg cataacgtcg caagaccaaa gagggggace ttcgggectc ttgccatcgg atgtgcccag atgggattag cttgttggtg gggtaacgge tcacctagge gacgatccet agctggtctg agaggatgac cagccacact ggaactgaga cacggtccag actcctacgggaggcagcag tggggaatat tgcacaatgg gcgcaagcct gatgcagcca tgccgcgtgtatgaagaagg cettcgggtt gtaaagtact ttcagcgggg aggaagggag taaagttaat acctttgctc attgacgtta cccgcagaag aagcaccggc taactccgtg ccagcagccg cggtaatacg gagggtgcaa gegttaatcg gaattactgg gcgtaaagcg cacgcaggcggtttgttaag tcagatgtga aatccccggg ctcaacctgg gaactgcatc tgatactggcaagcttgagtc

- Enterobacter cancerogenus strain MAB-1; GenBank: JX827382.

ggggagtacg gecgcaaggt taaaactcaa atgaattgac gggggeccgc acaagcggtggagcatgtgg tttaattcga tgcaacgcga agaaccttac ctactcttga catccagagaacttagcaga gatgctttgg tgccttcggg aactctgaga caggtgctge atggetgtcgtcagctcgtg ttgtgaaatg ttgggttaag tcccgcaacg agcgcaacce ttatectttg ttgccagcgg tccggccggg aactcaaagg agactgecag tgataaactg gaggaaggtg gggatgacgt caagtcatca tggccettac gagtagggct acacacgtgc tacaatggegcatacaaaga gaagcgacct cgcgagagca agcggacctc ataaagtgeg tcgtagtccggattggagtc tgcaactcga ctccatgaagtcggaatcgctagtaatcgt ggatcag

\section{- Shigella dysenteriae strain CNK-77; GenBank: JX827386}

tacacatgca gtcgtgcaag gtaccaagac tttgttcttt tgcttcgag tgggggaggg gtgagtaatg tgtgggaaac tgcctgatgg aggggattaa ctactggacc ggtacttaataccgcataac gtcttaagac caaggagggg gaccttcggg cctcttgcca tcggatgtgeccgaatggga ttcgctagta tgtggggtaa cggctcacct aggccaccat ccctaccaggt ctgacagga tgaccagcca cattggaact gatacacggt ccacactcct acggcacgcaggggtgggga atattgcaca ttgggcgcaa tgctgaagca cccgtgccgc gtgtatgacg aaggcettca ggttttcag atcttcaactgggatgaag ggaaaaagt tattaacttgctctgtgtg tttcccegca gaacaatctt agaataactc cgtgccatcc gecgcggcagta cggagggt gcaagcgtga atcggaatta ctggacttat agcgcacgca ggcggcttgtgcggtcetat gtgtaatccc cgagctcccctgctaactg caggagatac tgtcaagctt gagtct

- Enterobacter cowanii strain RMB-3 ;GenBank: JX827387.1

catacacatgcagtcgtacaagagtaacgcaagcagcttgctggtttgctgacgagtggcggacgggtgagtaatgtctggga aactgcctgatggagggggataactactggaaacggtagctaataccgcataacgtcgcaagaccgaagagggggaccttc gggcctcttgccatcggatgtgcccagatgggattagctagtaggtggggtaacggctcacctaggegacgatccctagctgg tctgagaggatgaccagccacactggaactgaacacggtccagactcctacgggaggcagcagtggggaatattgcacaa tgggcgcaagcctgatgcagccatgccgcgtgtatgaagaaggcettcgggttgtaaagtacttcagcggggaggaaggcg ataaggttaa taaccttgtc gattgacgtt accegcagaa gaagcaccgg ctaactccgt gecagc 


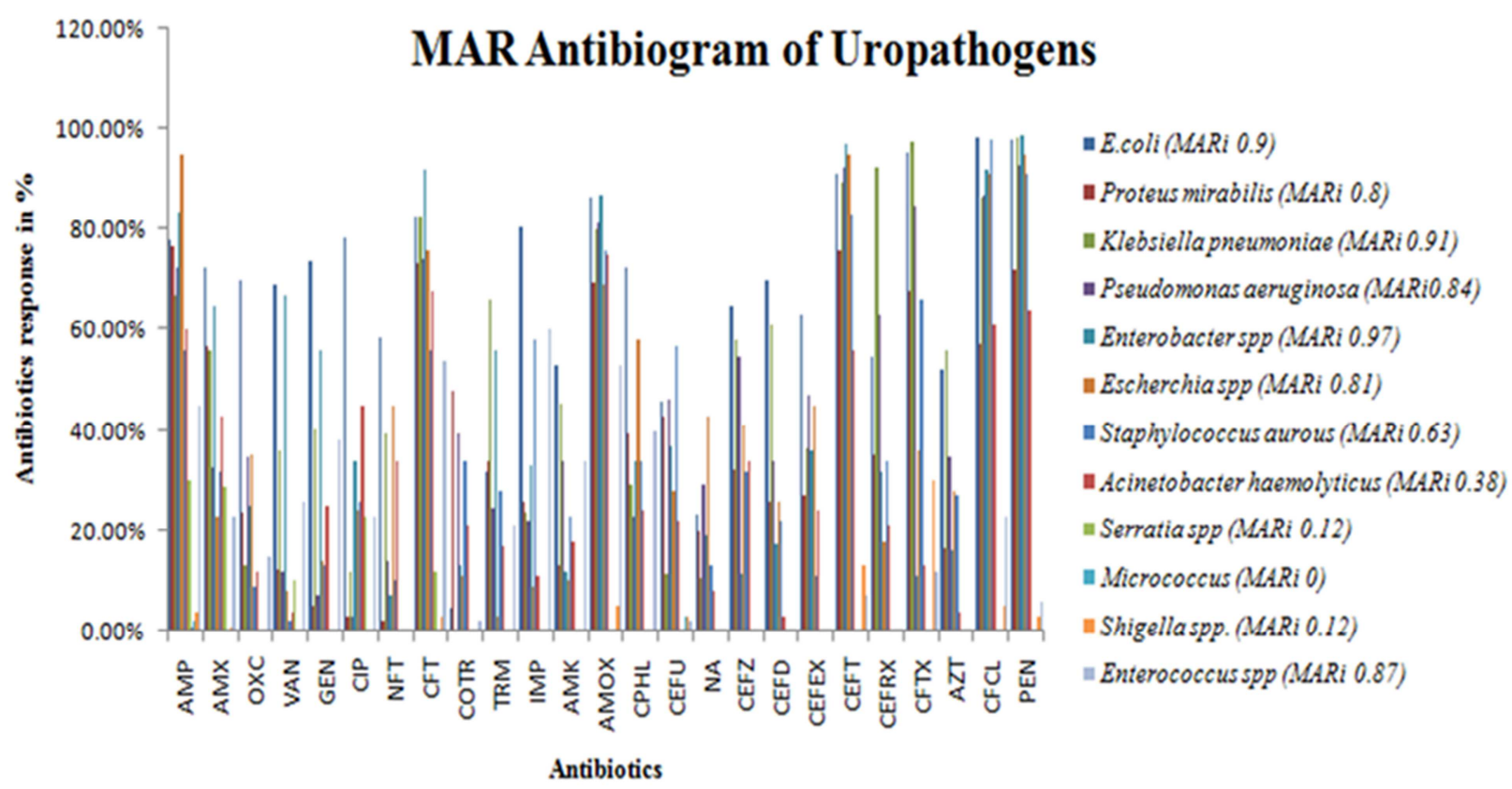

$\mathrm{n}=549 ; \mathrm{MDR}=170$ isolates. (Out of 549 isolates only 170 uropa thogens revealed MDR

activity)

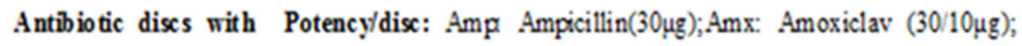

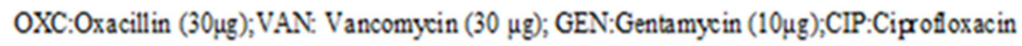

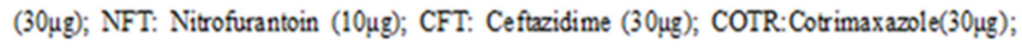

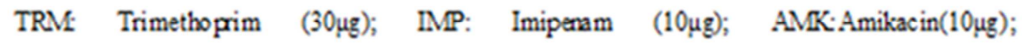

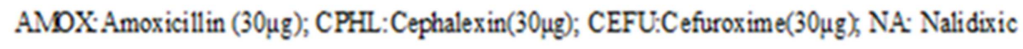

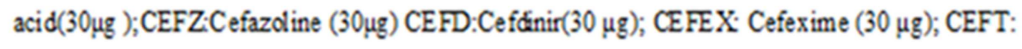
Ceftriaxone $(30 \mu g)$; CEFRX Cefuraxime $(30 \mu g)$; CFTX: Cefotaxime (30 $\mu g)$;

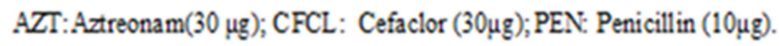

Fig. 1. Screening of uropathogens for MAR antibiogram and MAR Index with respect to $\beta$-lactam class.

S.aureus, MARi index 0.63 were found $100 \%$ sensitive to Vancomycin, $83 \%$ to Amikacin and Gentamicin each but were less susceptible to other common antibiotics. Coagulase-negative Staphylococcus were $80 \%$ sensitive to Vancomycin and Imipenem but relatively resisistant to other antibiotics Jones R. et al., 1999 reported similar study. As regards to Enterococci (MARi index 0.87), $83 \%$ of the isolates were resistant to Imipenem, $67 \%$ to Ciprofloxacin, $50 \%$ to each of Vancomycin, Gentamicin and Ceftriaxone. A report from SENTRY antimicrobial surveillance program, USA also reported the similar results. The Staphylococcus, Acinetobacter, Serratia spp and Shigella spp were exhibited high drug resistance towards third generation $\beta$-lactam antibiotics with MARi index of $0.63,0.38,0.12$ and 0.12 respectively. If MAR index of isolated bacteria is greater than 0.2 then it implies that strains of such bacteria originate from an environment where several antibiotics are used. MAR index of isolates in present study indicate large portion of bacteria were exposed to the antibiotics showing MAR index more than 0.2 . It may be due to large portion of the bacterial isolate being previously exposed to several antibiotics. The present data gives idea about the common trend of increased antibiotic resistance of uropathogens in this region (Nanded), which may be due to geographic variation or indiscriminate or sublethal use of antibiotics. This data not only help in proper treatment of UTI patients but helps to prevent further development of bacterial drug resistance by limiting the use of antibiotics. Finally, since the hospital environment is a sort of collection agency for many pathogenic microorganisms by virtue of many seriously ill patient who passes through it therefore it is extremely important for the hospital management to do everything possible to minimize the spread of these organisms to other patients. A high isolation rate of pathogens from urine samples of clinically suspected UTI shows a good correlation between clinical findings and microbiological methods. Gram-negative bacteria from Enterobacteriaceae family were the commonest organisms isolated.

Out of screened drug resistant uropathogens 7 promiant $\beta$ lactamase producers such as, Extended spectrum $\beta$ lactamases, Metallo- $\beta$-lactamases, Amp C $\beta$-lactamases etc. were identified by molecular identification method $(16 \mathrm{~S} \mathrm{r}$ RNA). All these novel isolates revealed to be having all $\beta$ lactamases in a single strain. We submitted this data on www.ncbi.com to GENBANK for sequence submission (Table 5) having accession numbers: Escherichia fergusonii 
strain GCR -1; GenBank: JX827388.1, Shigella flexneri strain DMB-1; GenBank: JX827385, Enterococcus faecalis strain ADR-1; GenBank: JX827384.1, Shigella flexneri strain SMB-11; GenBank: JX827383.1, Enterobacter cowanii strain RMB-3; GenBank: JX827387.1, Shigella dysenteriae strain CNK-77; GenBank: JX827386Enterobacter cancerogenus strain MAB-1; GenBank: JX827382.

In the Double disc synergy test, the combinations of Cefotaxime against Amoxicillin / Clavulanic acid with Ceftazidime of all isolates were found to be positive. We agree with observations of previous studies considering ceftazidime to be most effective in detecting ESBL producers among the 3GCs. The strength of our study is that, in our study population the percentage of ESBL producers detected by the phenotypic confirmatory method also produced MBL by Imipenem-EDTA method and Amp $C \beta$-lactamase by Three dimentional extract method.

Methods of detecting ESBL producing bacteria have been evolving for more than a decade, beginning with the description of the disc approximation test [35] and subsequently described by Jarlier V. et al. 1988 [36]. The three-dimensional test is a more sensitive procedure for the detection of ESBLs. However, this technique had its own limitations. Subsequently, the test was modified with the use of a slit technique with bacterial suspensions and enzyme extracts, but filling these slits was a fastidious procedure. Despite different modifications tried by various researchers, to date, no satisfactory technique has been established. Bearing all these points in mind, we tried some modifications in search of a simple and more user-friendly procedure than existing conventional phenotypic tests. In the modifications for enzymic extracts, all AmpC and ESBL producing bacterial isolates were detected correctly by the designed modifications (trenches/wells). Comparing the modifications with the conventional slit test, the enhanced growth of surface organisms was interpreted more easily in the designed modifications [Figure .2, 3, 4, 5, 6]. All the ESBL and AmpC producing isolates were detected correctly by adopting this method.

MBL production has been previously reported from India [37-39]. Most studies have used IPM-EDTA combined disc, Double Disc Synergy test using IPM-EDTA and modified With the Imipenem and EDTA combined disc test with a cutoff $>7 \mathrm{~mm}$, the positive and negative results were more clearly discriminated. The combined disc method using Imipenem + EDTA [Fig.3] was found to be superior to DDST (using imipenem - EDTA) and EDTA disc potentiation with Ceftazidime, Cefotaxime, Ceftizoxime and Cefepime [40]. From this study, it was apparent that various different mechanisms exist for production of multiple $\beta$-Lactamases, especially in places where newer $\beta$ - Lactams were being routinely prescribed. In case of MBC, in some cases we got similar values as like MIC and total killing of bacteria took place at the same MIC concentration [Table 6].All novel isolates were further analyzed by phylogenetic tree analysis by CLUSTAL W 2 [Fig.7].

Bacterial virulence factors are responsible for pathogenicity and can be effective screening criteria to find out pathogenic nature of UTI pathogens. Thus all novel 7 MDR isolates were continued further for the determination of Virulence factors. All isolates were serum resistant, Colicin producers, haemolytic, Aerobactin producers and having Cell surface hydrophobic [Fig. 8, 9, 10, 11, 12].

The haemolysin, especially $\alpha$-haemolysin, also known as cytotoxic necrotizing factor, is strongly proinflammatory leading to secretion of IL - 6 sets pace for pathogenesis of renal disease. The capacity to cause MRHA is due to various adhesins mainly $\mathrm{P}$ fimbriae, $\mathrm{P}$ associated fimbriae, and FIC fimbriae as seen in pyelonephritis cases. These adhere to fibronectin on uroepithelial cells contributing to persistence. The cytolytic protein toxin secreted by most haemolytic E.coli strains is $\alpha$-haemolysin. These seven isolates produces cell associated lysin on blood agar plates and hence haemolysin cause a clear zone of lysis [41] [Fig.8]. In the present study, though the nature of haemolysin was not further characterized it can be considered as cytotoxic necrotising factor (haemolysin). The difference between cases and controls for production of haemolysin was highly significant $\mathrm{p}<0.001$ [42]. Hemolysin production was found to be broadly distributed, being the second most detected virulence factor among vaginal isolates [43].

All isolates were Colicin producers [Fig.9]. All seven isolates gave $1+, 3+, 4+$ grade clumping in $1 \mathrm{M}, 1.4 \mathrm{M}$ and 2 $\mathrm{M}$ ammonium sulphate concentrations respectively [Fig.10]. The role of cell surface hydrophobicity $(\mathrm{CSH})$ in mediating bacterial adherence to mammalian cells is reported elsewhere [44]. Crystalline surface layers "S" present on both Gramnegative and Gram-positive organisms, play a vital role [45]. Hydrophobicity is a recently described novel virulence mechanism by E.coli.

All investigated strains were aerobactin positive [Fig.11]. About $90 \%$ of urinary strains isolated from UTI patients produced aerobactin [28] which confers an advantage to bacterial strains for the colonization of the urinary tract. During parturition, the physical barriers of the cervix, vagina and vulva are compromised providing an opportunity for environmental bacteria to ascend in the genital tract causing uterine infection. This situation is in a dynamic flux, of regular contamination, followed by its clearing up and by spontaneous re-contamination of bacteria during the first weeks following parturition [47].

All isolates were revealed Human serum bactericidal activity at $2 \%$ concentration [Fig.12]. Moreover, serum resistance also supports the bacterial resistance to different drugs. As human body is a rich source of bacteria but due to the presence of such inherent antibiotic resistant pathogens the opportunists would be converted into virulent and drug resistant. Serum and antibiotic resistance are one of the survival strategies of the disease causing organisms to overcome the human immune defense mechanism, which is a matter of concern as far as the treatment of the disease. It is accepted fact that bacteria are killed by normal human serum through lytic activity of alternative complement system [48]. Bacterial resistance to killing by serum, results in individual 
or combined effects of capsular polysaccharide, $\mathrm{O}$ polysaccharide and surface proteins [49].

To our knowledge the methods of detection of the above mentioned virulence markers are reasonably easy and screening them in a clinical microbiology laboratory is a worthwhile exercise. Bacterial adherence to host cells is a crucial step in the initiation of various infectious diseases. Adherence factors facilitate the colonization of the urinary tract for ascending infection

Surveillance of resistance is essential to monitor and control the spread of antimicrobial resistance. The WHONET program provides uniform guidelines for performing antimicrobial susceptibility tests. It also provides software through which data from each laboratory is entered into a common code and file format for that laboratory. This data can be shared with another laboratory working on WHONET program for further collaboration and for implementation of various control measures.

All seven novel multiple $\beta$-lactamase producers were studied for sensitivity pattern against various antibiotics by WHONET 5.6 Software. Escherichia fergusonii GCR-1,
Shigella flexneri DMB-1, Enterococcus faecalis ADR-1, Enterobacter cowaniiRMB-3, Shigella dysenteriae CNK-77, Enterobacter cancerogenusMAB-1, revealed highest percentage of ESBL production. All isolates were $100 \%$ resistant to antibiotics according to histogram study [Fig.13]

The WHONET study shows that highest resistance was against ampicillin (94\%) followed by Nalidixic acid and Cotrimoxazole ( 86.4 and $80.8 \%$, respectively). Resistance rate to majority of drugs was $42-59 \%$. These include Clindamycin, Erythromycin, Netilmicin, Gentamicin, Ciprofloxacin, Norfloxacin, Piperacillin, Nitrofurantoin, Amikacin and Coamoxyclav. Resistance to Ceftazidime and Cefaperazone was 38.5 and $20.7 \%$, respectively. All data was entered into the program manually on a daily basis. A large number of permutation combinations were available in the program for analysis. Hence the species isolated, resistance rates and resistance phenotypes can be compared between hospitals, resistance problems can be recognized, and priorities for further research can be set based on solid epidemiological data by WHONET 5.6 software.

Table 6. Determination of Minimum Inhibitory Concentration (MIC).

\begin{tabular}{|c|c|c|c|c|c|c|c|c|c|c|}
\hline \multirow{2}{*}{ Strains } & \multicolumn{10}{|c|}{ Minimum Inhibitory Concentrations $(\mu \mathrm{g} / \mathrm{mL})$ Antibiotics } \\
\hline & AMP & AMX & OXC & VAN & GEN & CIP & NFT & CFT & COTR & TRM \\
\hline E. fergusonii GCR 1 & 0.001 & 256 & 10 & 0.05 & 0.1 & 256 & 4 & 1 & 0.5 & 2 \\
\hline Shigella flexneri DMB-1 & 32 & 30 & 0.1 & 0.01 & 240 & 1 & 0.5 & 1 & 32 & 16 \\
\hline Enterococcus faecalis $\mathrm{ADR}-1$ & 5 & 0.05 & 8 & 2 & 0.1 & 0.05 & 8 & 0.5 & 1 & 1 \\
\hline Shigella flexneri SMB-11 & $<0.2$ & 0.01 & 0.25 & 32 & 8 & 0.001 & 0.01 & 4 & 240 & 32 \\
\hline Enterobacter cancerogenus MAB-1 & 0.1 & 30 & 64 & 0.01 & $<0.2$ & 0.01 & 32 & 16 & 0.5 & 1 \\
\hline Shigella dysenteriae CNK-77 & 0.064 & 0.01 & 1 & 2 & 120 & 4 & 0.1 & 0.001 & 32 & 32 \\
\hline Enterobacter cowanii RMB-3 & 5 & 1 & 1 & 5 & 2 & 0.25 & 30 & 0.1 & 240 & 1 \\
\hline
\end{tabular}

AMP: Ampicillin; AMX: Amoxiclav; OXC:Oxacillin;VAN: Vancomycin; GEN:Gentamycin ;CIP: Ciprofloxacin; NFT: Nitrofurantoin; CFT: Ceftazidime; COTR: Cotrimaxazole; TRM: Trimethoprim

Table 6. Contd.

\begin{tabular}{|c|c|c|c|c|c|c|c|c|c|c|}
\hline \multirow{2}{*}{ Strains } & \multicolumn{10}{|c|}{ Minimum Inhibitory Concentrations $(\mu \mathrm{g} / \mathrm{mL})$ Antibiotics } \\
\hline & IMP & AMK & AMOX & CPHL & CEFU & NA & CEFZ & CEFD & CEFEX & CEFT \\
\hline E. fergusonii GCR 1 & $>256$ & 128 & $<0.2$ & 1 & 30 & 64 & 16 & 8 & 1 & 64 \\
\hline Shigella flexneri DMB-1 & 32 & 0.1 & 8 & 4 & 0.5 & $>256$ & 32 & 0.001 & 128 & 1 \\
\hline Enterococcus faecalis ADR-1 & 1 & 64 & 32 & $>240$ & 14 & 64 & 8 & 1 & 0.001 & 8 \\
\hline Shigella flexneri SMB-11 & 0.5 & 1 & 0.1 & 5 & 32 & 1 & 8 & 8 & 32 & 0.001 \\
\hline Enterobacter cancerogenus $\mathrm{MAB}-1$ & 0.1 & 2 & 128 & 128 & 1 & 0.5 & $<0.2$ & 64 & 1 & 0.1 \\
\hline Shigella dysenteriae CNK-77 & 4 & 0.5 & 32 & 64 & $<0.2$ & 2 & 5 & 8 & $<0.001$ & 0.001 \\
\hline Enterobacter cowanii RMB-3 & 1 & 2 & 64 & 30 & 128 & 32 & 8 & 64 & 0.4 & 64 \\
\hline
\end{tabular}

IMP: Imipenam; AMK: Amikacin; AMOX: Amoxicillin; CPHL: Cephalexin; CEFU: Cefuroxime; NA: Nalidixic acid; CEFZ: Cefazoline; CEFD: Cefdinir; CEFEX: Cefexime; CEFT: Ceftriaxone

Table 6. Contd..

\begin{tabular}{lllll}
\hline \multirow{2}{*}{ Strains } & \multicolumn{4}{l}{ Minimum Inhibitory Concentrations $(\boldsymbol{\mu g} / \mathbf{m L})$ Antibiotics } \\
\cline { 2 - 5 } & CEFRX & CFTX & AZT & CFCL \\
\hline E. fergusonii GCR 1 & 10 & 32 & 1 & 240 \\
Shigella flexneri DMB-1 & 4 & 0.01 & 0.12 & 5 \\
Enterococcus faecalis ADR-1 & 32 & 10 & 1 & 1 \\
Shigella flexneri SMB-11 & 8 & 8 & 4 & 128 \\
Enterobacter cancerogenus MAB-1 & 1 & 0.032 & 0.01 & 32 \\
Shigella dysenteriae CNK-77 & 5 & 30 & 128 & 480 \\
Enterobacter cowanii RMB-3 & 30 & 0.01 & 1 & 16 \\
\hline
\end{tabular}

CEFRX: Cefuroxime; CFTX: Cefotaxime; AZT: Aztreonam; CFCL: Cefaclor; PEN: Penicillin. 


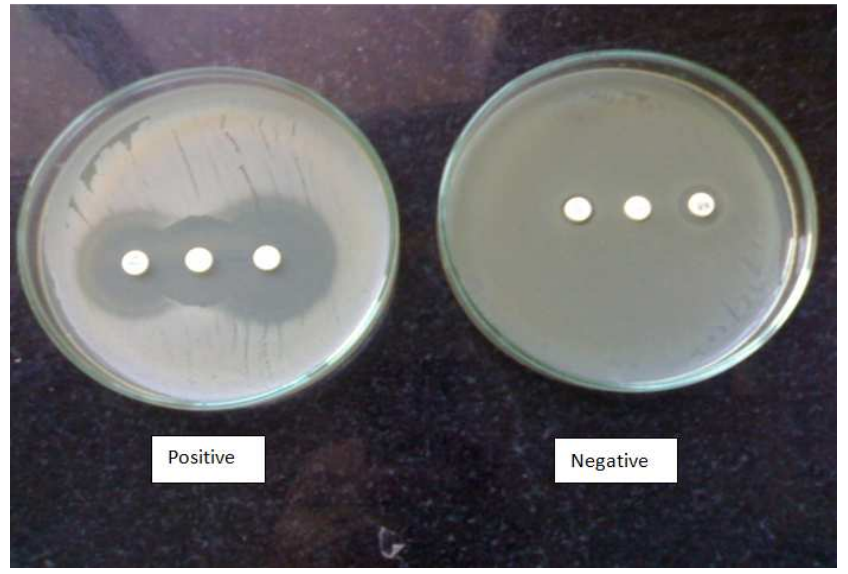

Fig. 2. Extended Spectrum $\beta$-lactamase Test.

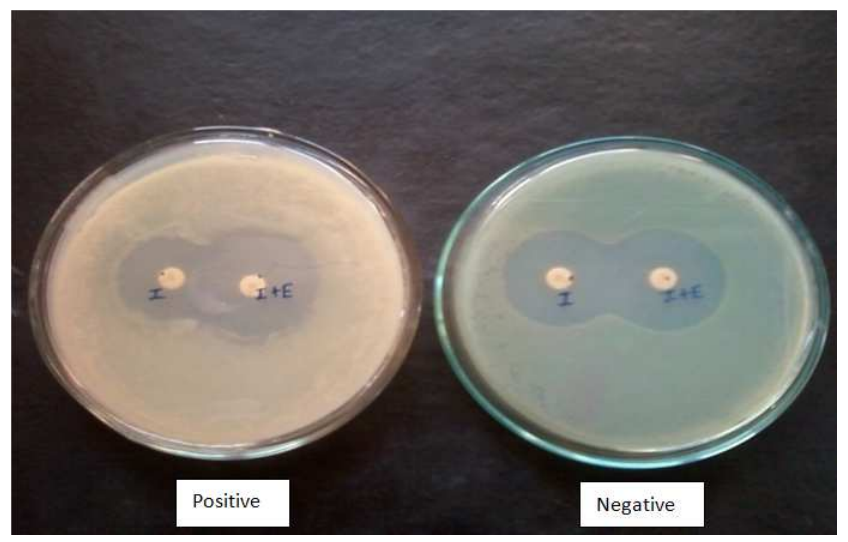

Fig. 3. Metallo $\beta$-lactamase Test.

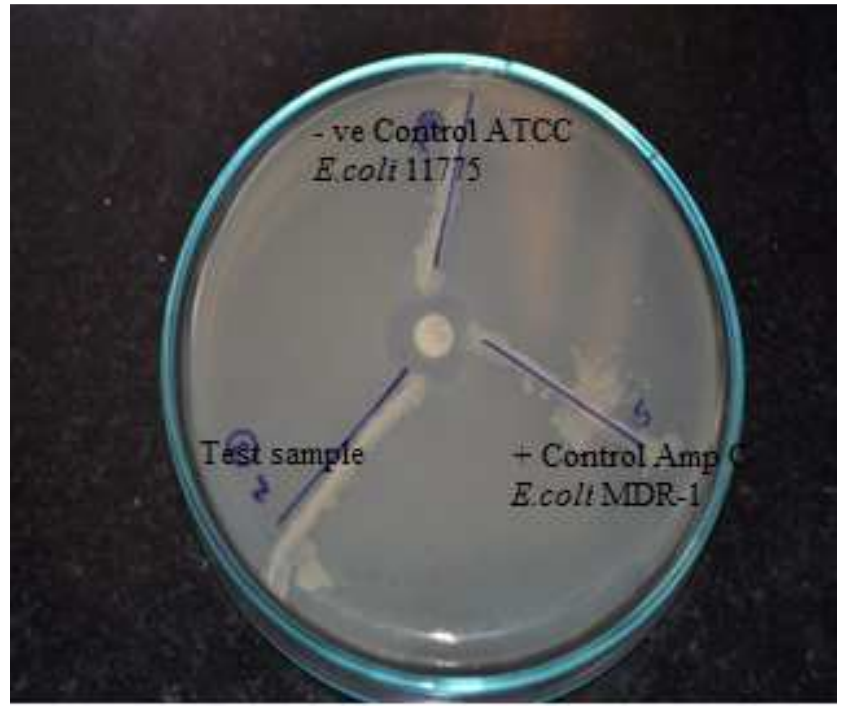

Fig. 4. Amp C $\beta$-lactamase Test.

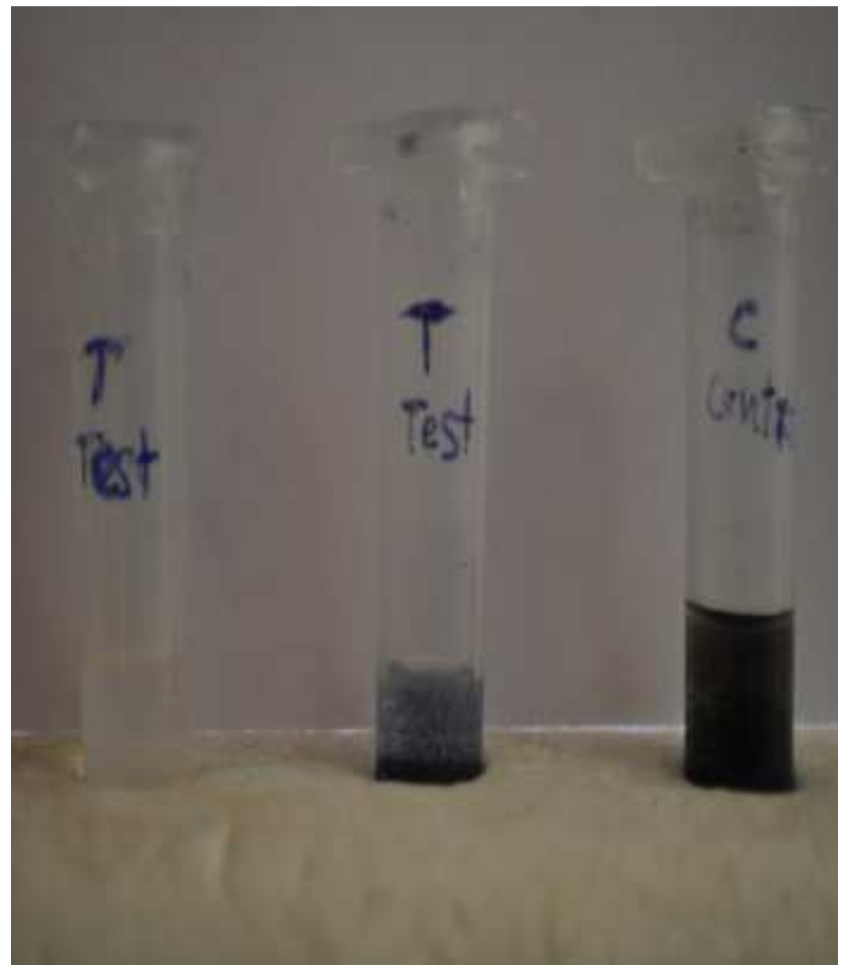

Fig. 5. Iodometric Test.

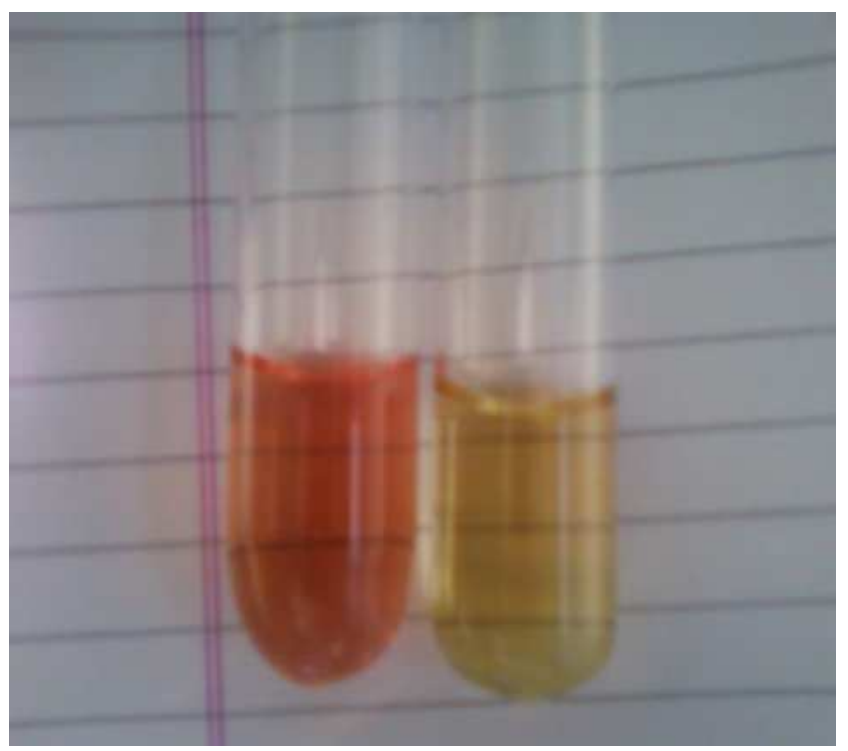

Fig. 6. Nitrocefin Test.

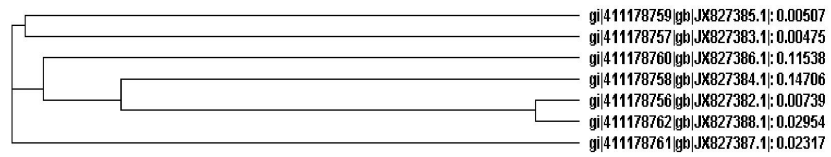

Fig. 7. Phylogenetic analysis of $\beta$-lactamase producers (Clustal w2). 


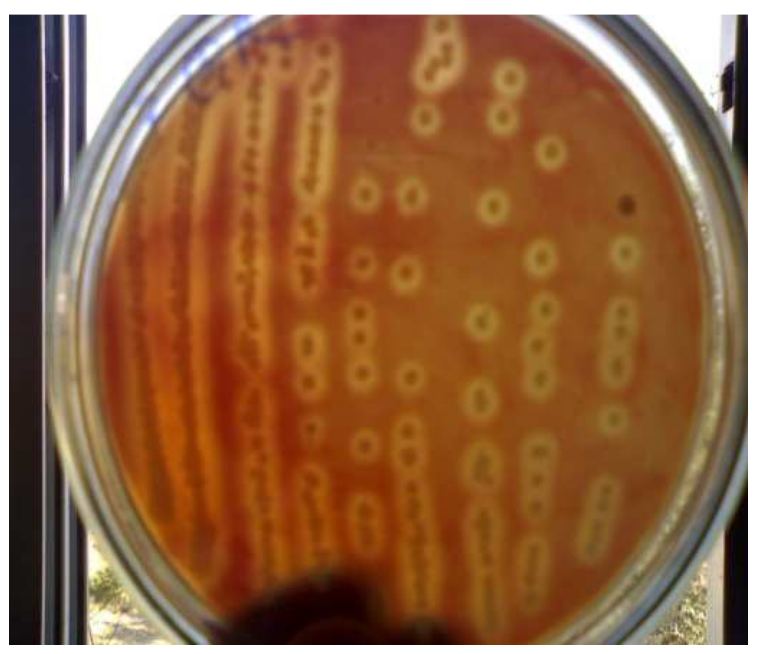

a) Production of $\alpha$-haemolysine

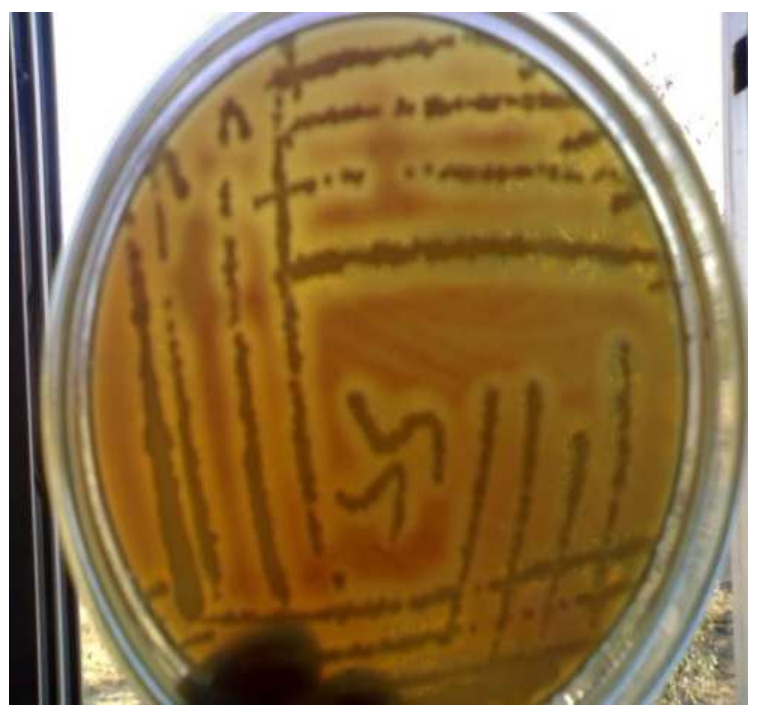

b) Production of $\beta$-haemolysine

Fig. 8. Hemolysin Production Test.

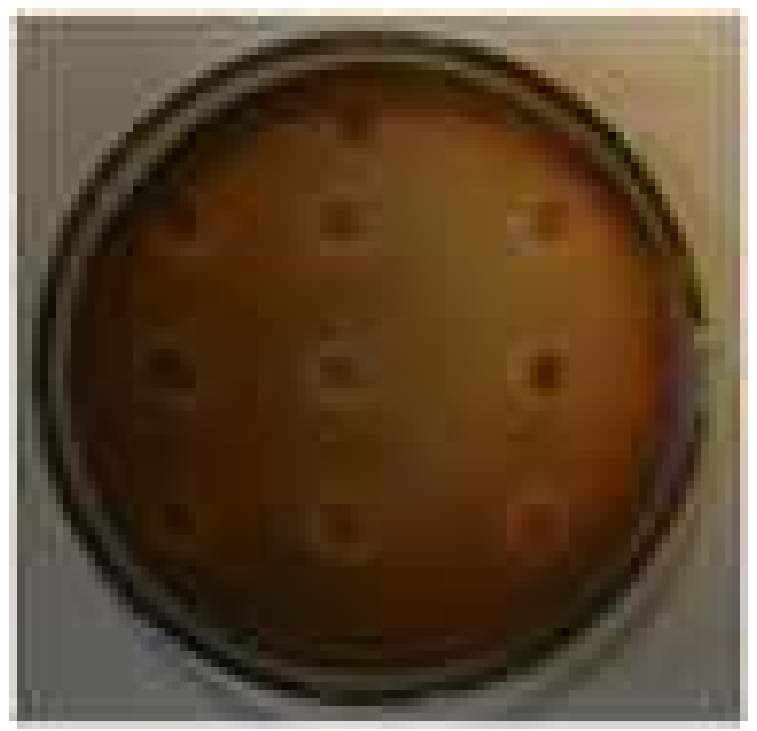

Fig. 9. Colicin Production Test.

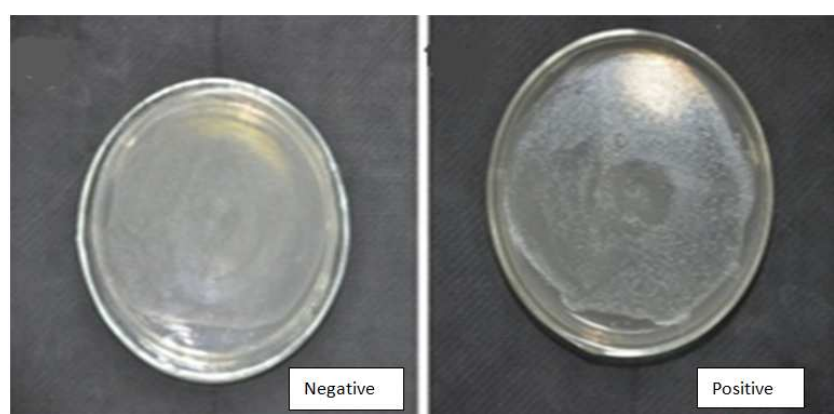

Fig. 10. Determination of Cell surface hydrophobicity.

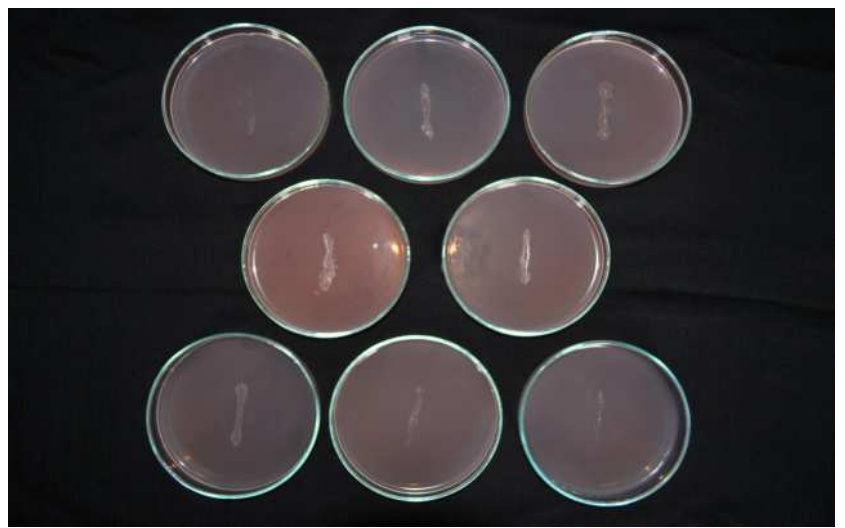

Fig. 11. Aerobactin Production Test.

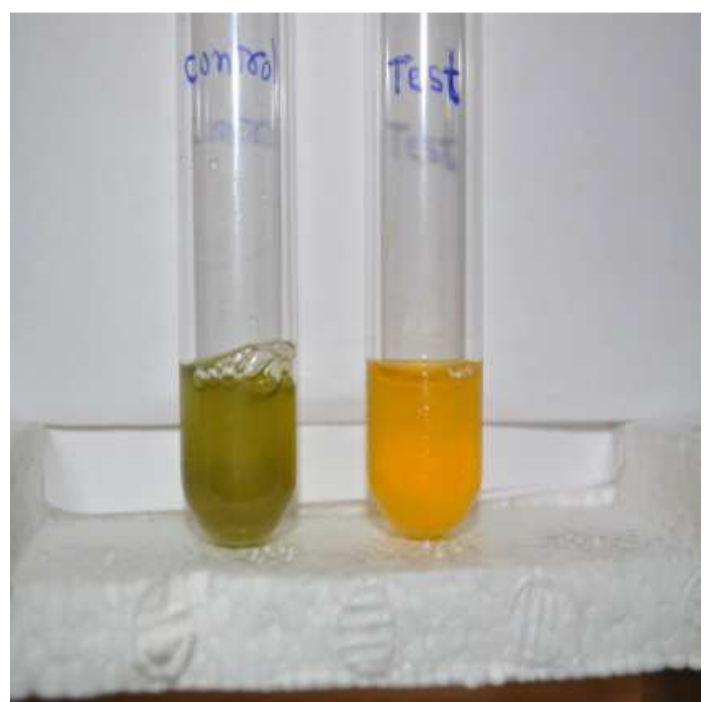

Fig. 12. Serum Resistance Test.

Resistant

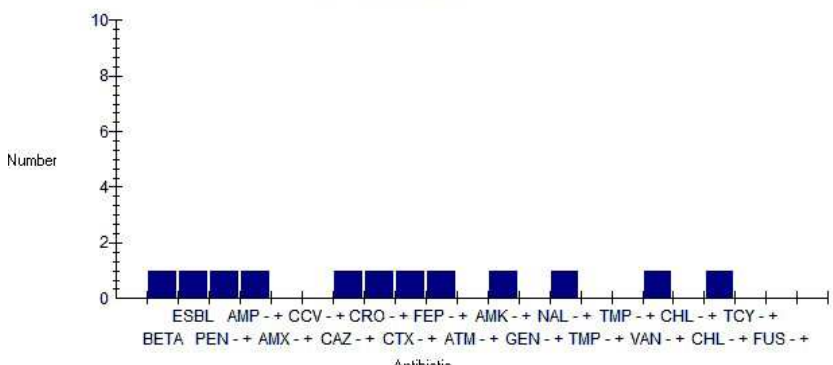



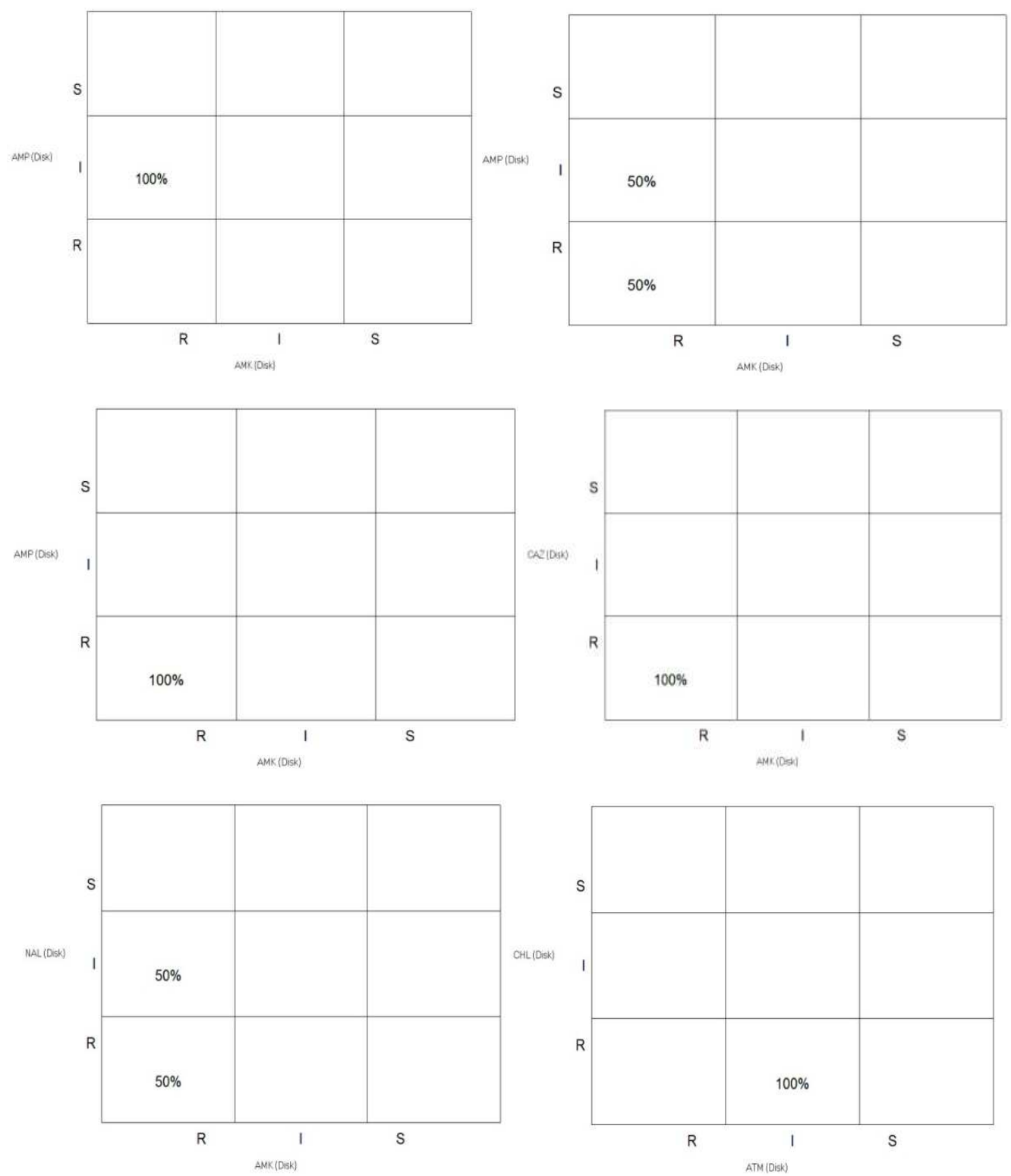

Fig. 13. Histograms.

\section{Conclusion}

The distribution of pathogens that cause UTI is challenging. The antibiotic resistance is on the increase state globally especially among Gram-negative bacteria. Therefore, there is a need for periodic antibiotic resistance survey to help physicians and the local population on the best treatment strategies. NCCLS should come up with a standard technique that will be easy and fast in detecting ESBL from both Enterobactericeae and other organism. They should also create awareness to both the clinician and the local population about the existence of ESBL and we suggest that more research should be embarked on search of an effective alternative antibiotic that can be used in treating infections caused by ESBL producing organisms. We can say the potential of this electronic network for studying the patterns and trends in the epidemiology of antimicrobial resistance in the various participating hospitals will help to contribute to identification of the main factors for the emergence of resistance, as well as the priorities for further investigating the genetic and molecular mechanisms responsible and thus for the development of a strategy to confront this major public health problem.

\section{Acknowledgment}

We gratefully acknowledge the Department of Science and Technology (DST), New Delhi, India for financial Assistance in the form of Fellowship through the grant [F.N: SR/WOSA/LS-305/2010]. 


\section{References}

[1] C. Raju, S. Tiwari, "Urinary tract infection-A suitable approach", Lecture notes. J. Ind. Acad. Clin. Med, Vol. 2, pp. 331-334, April 2004.

[2] V. Gupta, A. Yadav, R. Joshi, “Antibiotic resistance patterns in Uropathogens", Ind. J. Med. Microbiol, Vol. 20, pp.96-98, 2002.

[3] H. Ogawara, "Antibiotic resistance in pathogenic bacteria, with special reference to $\beta$-lactam antibiotics", Microbiol. Rev, Vol. 45, pp. 591-619, 1981.

[4] P. Bradford, "Extended-spectrum $\beta$-lactamases in the $21 \mathrm{st}$ century: Characterization, Epidemiology, and detection of this important resistance threat". Clin. Microbiol. Rev, Vol.14, pp. 933-951, 2001.

[5] E. Sturnberg, D. Mack, "Extended spectrum $\beta$-lactamases: implications for the clinical microbiology laboratory, therapy and infection control,” J. Infction, Vol. 47, pp. 273-295, 2003.

[6] M. Mishra, "Heamagglutination, Hemolysin production and Serum resistance of Proteus and related species isolated from clinical sources”, Ind. J. Med. Microbiol, Vol. 19 pp. 91, 2001.

[7] L. Emody, M. Kerenyl, G. Nagy, "Virulence factors of uropathogenic Escherichia coli," Int. J. Antimicrob. Agents, Vol. 22, pp. S22-S33, 2003.

[8] National Committee for Clinical Laboratory Standards (NCCLS), "Performance standard for antimicrobial susceptibility testing, M100-S9. Pennsylvania, 2002.

[9] R. Maskell, "Diagnosis of urinary tract infection, its causes and consequences. In: Urinary tract infection", Curr. Top. Infect. Series. 3M Edward Arnold. London, pp. 21-41, 1982.

[10] I. Porter, J. Bordie, "Boric acid preservation of urine samples”, Brit. Med. J, Vol. 2: 353-355, 1969.

[11] W. Stamm, G. Counts, K. Running, "Diagnosis of coliforms infection in Acutely disuric Women," New. Eng. J. Med, Vol. 307, pp. 463-468, 1982.

[12] R. Stark, D. Maki, "Bacteriuria in the cauterized patient", N. Engl. J. Med, Vol. 311, pp.560-564, 1984.

[13] W. Martin, R. Brik, P. Yu, J. Washington II, "Identfication of members of family Enterobacteriaceae by the R-B system", Appl. Microbiol, Vol. 20, pp. 880-883, 1970.

[14] P. Smith, A. Morris, L. Relier, "Predicting urine culture results by dipstick testing and phase contrast microscopy", Pathol, Vol. 35,pp. 161-165,February 2003.

[15] M. Cheesbrough, "District laboratory practice in Tropical countries. Cambridge United Press, U.K., Vol. 27, pp. 105, 2000 .

[16] M. Cheesbrough, "In: Medical Laboratory Manual for Tropical Diseases. Vol II ESBLS. Tropical Health. Technology, pp60-69,198-205,147-8,154-5,415,537-43, 1985.

[17] S. Khan, A. Ahmed, "Uropathogens and their susceptibility pattern: a restrospective analysis", J. Pak. Med. Asso, Vol.51, pp.98-100, 2001.
[18] A. Bauer, M. Kirby, C. Sherries, M. Turch, "Antibiotic susceptibility testing by a standard single Disc method," Am. J. Clin. Pathol, Vol. 45, pp. 494-496, 1966.

[19] D. Livermore, " $\beta$-lactamases in laboratory and clinical resistance," Clin. Microbiol. Rev, Vol.8, pp.557-584, 1995.

[20] Clinical Laboratory Standard Institute Performance standards for antimicrobial susceptibility testing. Twelfth informational supplement M100-S12.Wayne: CLSI; 2002.

[21] B Behera1, P. Mathur, A. Das, A. Kapil, V. Sharma, "An evaluation of four different phenotypic techniques for detection of metallo- $\beta$-lactamase producing Pseudomonas aeruginosa", Ind. J. Med.Microbiol.Vol.26,pp.233-237,March 2008.

[22] P. Coudron, E. Moland, K. Thomson, "Occurrence and detection of AmpC $\beta$-lactamases among Escherichia coli, Klebsiella pneumoniae and Proteus mirabilis isolates at a Veterans Medical Centre", J. Clin. Microbiol, Vol. 38, pp. 1791-6, 2000.

[23] R. Abbas, "Effect of Sub-inhibitory Concentrations of Gentamicin on the $\beta$-lactamase Production of Uropathogenic Escherichia Coli”, Res. J. Med. Sci, Vol.1,pp.63-67,2006.

[24] G. Ross, K. Chanter, A. Harris, S. Kirby, "Comparison of assay techniques for $\beta$-lactamase activity," Anal. Biochem, Vol. 54, pp. 9-16, 1973.

[25] S. Maji, P. Dandapat, D. Ojha, C. Maity, S. Halder, P. Mohapatra, "In vitro antimicrobial potentialities of different solvent extracts of ethanomedicinal plants against clinically isolated human pathogens," J. Phytology, Vol. 2, pp.57-64,2010.

[26] J. Sambrook, E. Fritsch, T. Maniatis, "Molecular cloning: a laboratory manual. New York: Cold Spring Harbor Laboratory, 1989.

[27] M. Vidotto, E.Muller, J. Freitas,A. Alfieri, I. Guimaras, D. Santos, "Virulence factors of avian Escherchia coli,".Avian. Dis, Vol. 34, pp. 531-538, 1990.

[28] B. Brito, D. Leitte, "Virulence-associated factors of uropathogenic Escherichia coli strains isolated from pigs," Vet. Microbiol, Vol. 65, pp. 123-132, 1999.

[29] J. Blanco, M. Alonso, E. Gonzalez E, "Virulence factors of bacteriemic Escherichia coli with particular reference to production of cytotoxic necrotizing factor (CNF) by $\mathrm{P}$ fimbriated strains", J. Med. Microbiol, Vol.31.pp.175-183,1990.

[30] K.Timmis, "Plasmid gene that specifies resistance to the bactericidal activity of serum, in Plasmids of medical, environmental and commercial importance", edited by K N Timmis \& Puhler (Elsevier, North Holland Biomedical Press, New York), 145-153, 1979.

[31] J. Plorade, J. Sherris, K. Ryan, C. Georgeray, "Urinary tract infection. in: medical microbiology 1st ed . Elsevier New York * Amsterdam * Oxford ESBL," Tropical Health Technology / Butterworth, Pp. 601-7, 247-8, 1984.

[32] M. Manjula, D. Priya, G. Varsha, "Detection of extended spectrum $\beta$-lactamases producers among surgical wound infections and burn patients in JIMPMER", Ind. J. Med .Microbiol, Vol.18, pp. 160-165, 2006.

[33] R. Jones , K. Kugler, M. Pfaller, P. Winokur, "Characteristics of pathogens causing Urinary tract infections in hospitals in North America. Results from the SENTRY antimicrobial Surveillance Program1997,'Diagn. Microbiol. Infect. Dis, Vol. 33, pp. 55-63, 1999. 
[34] G. Kahlmeter, "An international survey of the antimicrobial susceptibility of pathogens from uncomplicated Urinary tract infections: the ECO.SENS Project," J. Antimicrob. Chemother, Vol. 51, pp. 69-76, 2003.

[35] C. Brun-Buisson, P. Legrand, A. Phillippon, F. Montravers, M. Ansquer, J. Duval J, "Transferable enzymatic resistant to third generation cephalosporin during nosocomial out breaks of multi resistant Klebsiella pneumonia," Lancet. Vol. 2, pp.302-306, 1987.

[36] V. Jarlier, M. Nicolas, G. Fournier, "Extended broad-spectrum $\beta$-lactamases conferring transferable resistance to newer $\beta$ lactam agents in Enterobacteriaceae: hospital prevalence and susceptibility patterns," Rev. Infect. Dis, Vol.10, pp.867-78., 1988.

[37] B. Navneeth, D. Sridaran, D. Sahay, M. Belwadi, "A preliminary study of metallo- $\beta$-lactamase producing Pseudomonas aeruginosa in hospitalized patients," Ind. J. Med. Res, Vol. 116, pp.264-268, 2002.

[38] V. Gupta, P. Datta, J. Chander, "Prevalence of metallo- $\beta$ lactamase (MBL) producing Pseudomonas spp and Acinetobacter spp in a tertiary care hospital in India," J. Inf, Vol. 52, pp.311-4, 2006.

[39] M. Jesudason, A. Kandathil, V. Balaji, "Comparison of two methods to detect carbapenemase and metallo- $\beta$ - lactamase production in clinical isolates," Ind. J .Med. Res, Vol. 121, pp. 780-3, 2005.

[40] J. Yan, J. Wu, S. Tsai, C. Chuang, "Comparison of the double disk, combined-disk, and E Test methods for detecting metallo- $\beta$-lactamases in gram-negative bacilli”, Diagn. Microbiol. Inf. Dis, Vol.49, pp. 5-11, 2004.
[41] H. Smith, "The haemolysins of Escherichia coli," J. Pathol. Bacteriol, Vol. 85, pp. 197-211, 1963.

[42] J. Johnson, "Virulence factors in Escherichia coli urinary tract infection," Clin. Microbiol. Rev, Vol.4, pp. 81-128, 1991.

[43] J. Blanco, M. Alonso, E. Gonzalez E, "Virulence factors of bacteriemic Escherichia coli with particular reference to production of cytotoxic necrotizing factor (CNF) by Pfimbriated strains," J. Med. Microbiol, Vol.31pp.175-183, 1990.

[44] S. Mudd, E. Mudd, "The penetration of bacteria through capillary spaces IV. A kinetic mechanism in interfaces," J. Exp. Med, Vol.40, pp. 633-45, 1924.

[45] B. Sleytr, P. Messner, "Crystalline surface layers of bacteria," Ann. Rev. Microbiol, Vol. 37, pp. 311- 339, 1983.

[46] I. Sheldon, D. Noakes, A. Rycroft, "Effect of postpartum manual examination of the vagina on uterine bacterial contamination in cows," Vet. Rec, Vol. 151, pp.531-534, 2002.

[47] P. Taylor, "Bactericidal and bacteriolytic activity of serum against gram negative bacteria,"Microbiol. Rev, Vol.47, pp. 46-83, 1983.

[48] M. Montenegro, D. Bittersuermann, J. Jimmis, "Serum resistance and pathogenicity related factors in clinical isolates of Escherichia coli and other gram negative bacteria," J. Gen. Microbiol, Vol.131, pp. 1511-21.

[49] W. Stamm, "Scientific and clinical challenges in the management of urinary tract infections," Am. J. Med, Vol.113, pp. 1S-4S, 2002. 